This item was submitted to Loughborough's Research Repository by the author.

Items in Figshare are protected by copyright, with all rights reserved, unless otherwise indicated.

\title{
Whose day is it anyway? St. Patrick's Day as a contested performance of national and diasporic Irishness
}

\section{PLEASE CITE THE PUBLISHED VERSION}

http://dx.doi.org/10.1111/j.1754-9469.2011.01149.x

\section{PUBLISHER}

Association for the Study of Ethnicity and Nationalism/John Wiley \& Sons

\section{VERSION}

AM (Accepted Manuscript)

\section{PUBLISHER STATEMENT}

This work is made available according to the conditions of the Creative Commons Attribution-NonCommercialNoDerivatives 4.0 International (CC BY-NC-ND 4.0) licence. Full details of this licence are available at: https://creativecommons.org/licenses/by-nc-nd/4.0/

\section{LICENCE}

CC BY-NC-ND 4.0

\section{REPOSITORY RECORD}

Scully, Marc D.. 2019. "Whose Day Is It Anyway? St. Patrick's Day as a Contested Performance of National and Diasporic Irishness". figshare. https://hdl.handle.net/2134/25411. 


\title{
Whose day is it anyway? - St. Patrick's Day as a contested performance of national and diasporic Irishness. ${ }^{i}$
}

\begin{abstract}
One of the more intriguing aspects of St. Patrick's Day celebrations as a nationalised ritual of a performed Irishness, both within and outside Ireland is the extent to which it represents a dialogue between territorialised and diasporic expressions of Irish identity, and claims of belonging to Irishness. St. Patrick's Day celebrations in English cities are a particularly intriguing example of this contestation, due to the proximity of the two countries and the historical structural and cultural constraints on the public performance of Irish identity in England, as well as their more recent reinvention within celebratory multiculturalism. Based on my recent $\mathrm{PhD}$ research, this paper examines how debates around the authenticity of St. Patrick's Day parades in English cities are employed in the identity work of individual Irish people. In doing so, it provides insight on the tensions between Irishness as transnational, diasporic and ethnic, as experienced in England.
\end{abstract}

\section{Introduction}

The recent custom of senior Irish government figures visiting major cities around the globe to commemorate the Irish national holiday of St. Patrick's Day was invested with a particular political significance in March 2011. For the newly elected government, it was an early opportunity to occupy the space long held by their political rivals on the world stage. It was also an opportunity for the new administration to demonstrate to a domestic audience the clear difference between themselves and their predecessors. Reacting to a public perception that St. Patrick's Day visits abroad had become little more than junkets for the political class, the number of ministers travelling was reduced from 22 to 9 , and the focus of the visits was recalibrated to explicitly promote tourism and trade, in a calculated effort to communicate that Ireland under its new government could promise a rapid recovery from the financial travails of 2010 culminating in the EU-IMF bailout. In the words of Taoiseach ${ }^{\text {ii }}$ Enda Kenny, Ireland was now open for business.

While the majority of press coverage of government figures abroad inevitably focussed on Kenny's presentation of a bowl of shamrock to U.S. President Barack Obama in Washington D.C. and the photo opportunities that provided, Tánaiste ${ }^{\mathrm{iii}}$ and Minister for Foreign Affairs \& Trade Eamon Gilmore's visit to New York was arguably the more interesting. Over the course of his stay, Gilmore intervened in the long-running dispute regarding the participation of LGBT groups in the New York City St. Patrick's Day parade ${ }^{\text {iv }}$. In a meeting with LGBT community leaders, he criticised the organisers of the parade, the Ancient Order of Hibernians, for continuing to exclude LGBT groups, arguing that 'what these parades are about is a celebration of Ireland and Irishness. I think they need to celebrate Ireland as it is, 
not as people imagine it. Equality is very much at the centre of who we are in our identity in Ireland. This issue of exclusion is not Irish, let's be clear about it. Exclusion is not an Irish thing ... I think that's the message that needs to be driven home' (O'Doherty, 2011).

Kenny and Gilmore's presence in the United States for St. Patrick's Day illustrate the nature of the feast as representing the relationship between Ireland and the Irish diaspora in microcosm. The White House meeting between Obama ${ }^{\mathrm{v}}$ and Kenny can be seen as a direct appeal to the political and economic power of Irish America, a term which is often used within Ireland as commensurate with the Irish diaspora as a whole. Meanwhile, Gilmore in critiquing the authenticity of the performance of Irishness in the New York St. Patrick's Day parade, reopened the argument as to whether the Irish state has any legitimacy to define the contours taken by Irishness abroad, as previously recounted by Gray (2002). Above all, the very fact that senior members of the Irish government spend the Irish national holiday abroad, rather than in Ireland illustrates the global reach of the concept of St. Patrick's Day, which is largely attributable to the Irish diaspora. Indeed, it can be convincingly argued that St. Patrick's Day as it is currently understood is far more a creation of the Irish diaspora than of the Irish nation-state.

As opposed to the state discourses of diasporic Irishness on St. Patrick's Day which, as illustrated above, are often employed towards political and economic ends, this paper takes a social psychological approach in exploring how St. Patrick's Day is experienced and celebrated by individual members of the diaspora. The celebration of St. Patrick's Day in the English cities of London and Birmingham will be focussed upon as providing a unique example of a feast that is simultaneously transnational and diasporic, as well as a strand of the form of 'celebratory multiculturalism' that has developed within the British ${ }^{\mathrm{vi}}$ polity. In order to situate this in the appropriate context, it is first necessary to give a brief account of the diasporic antecedents of St. Patrick's Day.

\section{St. Patrick's Day as a diasporic holiday.}

It is notable that current understandings of the 'traditional' means of celebrating St. Patrick's Day, as a public, 'carnivalesque' celebration of all things Irish, is by and large a creation of the diaspora, and in particular the Irish in America. In their history of St. Patrick's Day celebrations, Cronin \& Adair (2002) note how festivities within Ireland were seen as rather drab compared to those in New York and Boston: 'there was a feeling that the American tradition of celebrating St. Patrick's Day was long-standing and ongoing, whereas events in Ireland were poor copies' (Cronin \& Adair, 2002, p. 188). There is a certain irony here given the extent to which Irishness has been assumed by those within Ireland to be the preserve of the Irish nation-state, that St. Patrick's Day parades held in Ireland were seen as inauthentic copies of the 'real thing', which was presumed to be happening on the streets of New York or Boston.

It should be mentioned that the St. Patrick's Day parades in Dublin were given something of a new lease of life by their re-invention in 1996 as part of a week-long Festival. This was specifically done, as stated by the festival website (St. Patrick's Festival, 2010) in order so that Ireland the nation-state, might regain ownership of the Day, and that Dublin would be repositioned at the centre of the global celebrations. This effort to promote a St. Patrick's Day celebration more in keeping with current discourses of Irishness within Ireland has been relatively successful, at least in commercial terms, with recent estimates suggesting the festival is worth $€ 58.3 \mathrm{~m}$ to the Irish economy (Sweeney, 2010). However, St. Patrick's Day remains something of a cipher through which Irishness in Ireland and the Irishness of the 
diaspora are forced to engage with one another at least once a year, and, significantly, it is still perhaps the one time of the year where territorialised versions of Irishness do not have the upper hand. This may, at least in part, account for some of the hostile reactions to 'inauthentic' versions of Irishness performed as aspects of St. Patrick's Day parades outside Ireland.

This conversation between Ireland and its diaspora is largely between Ireland and IrishAmerica, however. Despite the proximity of England to Ireland, and a long history of St. Patrick's Day celebrations and parades being carried out in English cities in some form, the way in which St. Patrick's Day is celebrated in England does not appear to inhabit discourses around the day in the same way as the Irish-American tradition. In part, this is attributable to political reasons and in keeping with the broader experience of the Irish in England as being an 'invisible' migrant group for large periods of recent history (Hickman, 1998; Mac an Ghaill, 2000, 2001). Despite a history of sectarian contestation of large-scale parades, particularly in cities such as Liverpool, during the 1960s, as outlined by Cronin and Adair, St. Patrick's Day events had become relatively established in English cities and were regarded benignly, if not enthusiastically by the relevant authorities and the public at large. However, such public demonstrations of Irishness were regarded with outright hostility following the onset of IRA bombings of English cities, and the associated 'suspect community' period (Hillyard, 1993). The parade in Birmingham, previously one of the most high-profile in the country, was suspended indefinitely following the 1974 bombings of that city, while parades in other cities were confined to 'Irish areas' such as Brent in London, or more commonly, the day was celebrated in a less publicly visible way in Irish pubs and clubs. The one exception to this was a church-oriented parade organised by the Council of Irish County Associations in London, which continued throughout the 1970s and 1980s, although often in the face of much public hostility.

In recent years, dating from around the mid-1990s, and in line with the wider shift in how Irishness is viewed within England, large-scale high-profile St. Patrick's Day parades began to be staged once again on the streets of English cities. In some cases, this was deliberately framed as a re-emergence of the Irish in England, following the low-profile nature of the 'suspect community' years, and it was also framed as a reconciliation between the Irish community and the civic sphere. This was particularly apparent in the case of the Birmingham St. Patrick's Day Parade: Gudrun Limbrick's (2007) history of the parade in Birmingham places particular emphasis on the symbolic significance of the 1996 parade as the first to be held in the city since the 1974 bombings. For those involved in the parade, the re-emergence of the Irish in the public space of the city symbolised and was a step towards the acknowledgement of the role of the Irish in the public life of the city.

Similarly, in London, the revival of the parade in the city centre involved transferring the responsibility for the organisation of the parade from the Council of Irish County Associations to the Greater London Authority, who set about transforming the parade into a major feature of official London public life (Harrison, 2004). The Council of Irish County Associations continue to retain an advisory capacity as members of the St. Patrick's Day Advisory Forum, along with other interested groups. In addition to this, the festival is now organised in partnership with Tourism Ireland, the official agency promoting Ireland (on an all-Ireland basis) as a tourist destination. Therefore, the festival now also represents a showcase for selling Ireland around visions of how 'native' tourist agencies wish to portray Irishness.

Meanwhile, it should also be noted that while the nature of St. Patrick's Day celebrations in England have changed, so too have the characteristics of the Irish population in England. 
While the large community parades of the 1950s and 1960s were largely associated with the wave of Irish migrants who arrived in England in the 1950s, this generation has since been supplemented both by subsequent waves of Irish migrants, particularly in the 1980s, and by the rise of a distinct second-generation Irish consciousness. The uneven geographical spread of these successive waves also needs to be taken into account, with Irish communities in the north-west of England largely having been shaped by $19^{\text {th }}$ and early $20^{\text {th }}$ Century migration, communities in the West Midlands being associated with the 1950s generation, and London and the South-East being the predominant destination for Irish migrants since the 1980s (Akenson, 1993; MacLaughlin, 1997; Neal, 1999; Walter, 2008b). The specificity of the make-up of the 'Irish community' within a specific city may be seen as an intensely localised influence on the forms St. Patrick's Day celebrations take, which have the potential to come in conflict with a globalised, commercialised understanding of the feast.

More recent Irish migrants have generally been depicted as being more middle-class than their predecessors and as seeking to distance themselves through various strategies from the 'oldfashioned' Irishness exemplified by established Irish communities (Gray, 1996, 1999, 2000, 2004; Hickman, 2002; Kells, 1995; Mac an Ghaill \& Haywood, 2003). It can also be argued that due to the greater ease of travel and communication between Ireland and England that these more recent migrants hold more transnational orientations and understandings of Irishness, where transnationalism is understood at the level of the individual as living in two or more countries simultaneously, but retaining the understandings of national identity current in the nation of origin. Meanwhile, a hybridised form of specifically urban Irishness has emerged among those of Irish descent in England, so that hyphenated labels such as 'LondonIrish', 'Birmingham-Irish', 'Mancunian-Irish' etc. are now commonplace and are understood as denoting the specificity of second-generation Irish experience (Hickman, Morgan, Walter, \& Bradley, 2005; Leonard, 2005; Scully, 2010b; Walter, 2001). Given these material differences, the nature of what constitutes 'authentic' Irishness in England is constantly contested and renegotiated, thus adding to the difficulty of publicly celebrating an Irishness that would be recognised as 'authentic'.

It can be seen that as the parades have been revived, they are now required to fulfil a number of functions simultaneously. While the expectation of many Irish people might have been that the parades would be a community-orientated participatory event, much as they were in the years preceding the suspect community period, the 'carnivalesque' nature of the IrishAmerican parades now represented the dominant paradigm of St. Patrick's Day parades worldwide, and there may have been an expectation that parades held in English cities should follow this pattern. Practically, parades cannot now be run in large cities without co-operation from both local authorities and commercial sponsors who might have different expectations and demands of a St. Patrick's Day Parade, or St. Patrick's Festivals as they have now been largely re-branded. As such, this possible tension between 'parade' as participatory community event and 'festival' as spectacle, is an aspect of the tensions between visibility and essentialism in a multicultural setting.

\section{St. Patrick's Day as an 'ethnic' celebration in multicultural English cities}

The current position of St. Patrick's Day as a feature of the public life of the contemporary city needs to be understood in the context of the form of 'celebratory' urban multiculturalism that has developed in Britain over the last 25 years. Underpinned by a 'politics of recognition' (Taylor, 1994), one of the means of counteracting the 'oppressive' nature of misrecognition 
through multicultural policies has through sponsoring initiatives designed to promote crosscultural dialogue and a heightened appreciation of the cultural forms of minority groups. However, it has been argued that this focus on 'celebration' has glossed over the structural inequalities and institutional discrimination faced by minority individuals (Brah, 1996; Hesse, 2000). Furthermore, it is debateable just how much space 'celebratory multiculturalism', which has also been referred to 'boutique multiculturalism', or 'saris, samosas and steel drums' multiculturalism offers for the articulation of minority identities. It has been criticised for highlighting those exoticised aspects of minority culture that are palatable to the majority (by and large, English) culture and, in many instances allowing these to represent the entirety of the culture. ${ }^{\text {vii }}$ Thus, more 'problematic' aspects are glossed over to promote certain essentialised, reified versions of minority identities as representative of all those who may be covered by such an identity and in so doing valorise an artificial notion of 'community identities' at the expense of more nuanced individual expressions of identity (Anthias, 2002; Brubaker \& Cooper, 2000; Gilroy, 2005; Malik, 2010; Phoenix, 1998).

The recognition of the Irish as an ethnic minority in England, began with the appointment of an Irish liaison officer by the Greater London Council in 1983, spread to other metropolitan councils throughout the 1980s, and culminated, after much campaigning on the issue by Irish community groups, with the inclusion of an 'Irish' category in the ethnic monitoring section of the 2001 census for England and Wales. Alongside this form of official recognition, Irish community groups, such as the Irish in Britain Representation Group, campaigned to promote a more positive public depiction of Irishness to counteract the negative stereotyping of the Irish especially prevalent during the 'suspect community' period of the 1970s and 1980s (Curtis, 1984; Nagle, 2009).

Possibly partly as a result of these initiatives, and undoubtedly helped by the advent of the Peace Process in Northern Ireland, the public depiction of Irishness in England has become far more positive (although not necessarily more informed) within the past 15 years. The current political and social environment therefore permits large, multifaceted celebrations of St. Patrick's Day in English cities in ways that were not previously possible ${ }^{\text {viii }}$. However, it can be argued that these celebrations are as subject to the failings of multicultural representation as anything else. If there is a specific form of 'saris, samosas and steel drums' multiculturalism that applies to the Irish, this could be termed 'Craic, céilís and Celticism'. Nagle (2005) has argued that the success of a certain type of Irishness, often characterised by a sort of primitivist Celtic-tinged celebration is an example of 'acceptable alterity' and that Irishness is only allowed to enhance Britain's rich, cultural heterogeneity in certain sites and on certain terms. This has the potential to cause tensions between those who might see this as a worthwhile exercise in strategic essentialism and those who feel it represents a misrepresentation of Irishness.

Nagle highlighted this tension in his discussion of the 2002 London St. Patrick's Day Parade and suggested that the role of local government and multicultural corporations in sponsoring the celebrations may have shaped the nature of the celebrations and choices over the way Irishness was represented within the parade i.e. as a form of commercialised Celticism to be marketed as an 'alternative way of life', which those who are not Irish can buy into, if only for a day:

Many of the Irish agencies taking part in the parade were willing to include some representations of Irishness that played on alterity: representations that foreground forms of Irish traditional music and dance that are connected to visions of Celticism. In a postcolonial sense this is problematic, in that rather than traditional culture providing a source of counterhegemonic struggle against the imposition of an inferior Irish identity, it 
more likely represents the confirmation of essentialist notions of difference (Nagle, 2005, p. 569).

Nagle highlights the possible ambivalence of such events, as 'lying uneasily ... between an important politics of recognition and a dangerous reification of culture and ethnicity and the reduction of identities to a fetishized surplus value' (p.563), and describes this potential paradox as 'multiculturalism's double-bind' (Nagle, 2009). However, his analysis from attending the parade itself suggests that it defied co-option by any one group, or vision of Irishness, being rather characterised by nuance, fluidity and a self-reflexive plurality.

O'Keefe-Vignernon's (2008) research among patrons of Irish centres in Camden, Hammersmith, Haringey and Wimbledon presents a more ambivalent picture. The respondents in this research, while acknowledging that the official St. Patrick's Day parade had made the Irish in general more visible, were concerned about the image of Irishness being projected, describing it as 'slick' and dependent on 'the paddywhackery stuff, a lot of it clichéd' (O'Keeffe-Vigneron, 2008, p. 189).

Of course, as outlined above, it is unrealistic to expect the Irish population in England to speak with one voice on whether St. Patrick's Day celebrations are representative of an 'authentic' collective Irish identity in England, any more than it would be realistic to expect such a unitary collective identity to exist. What the parades do represent is a useful site through which to examine the contested nature of how Irishness is represented publicly in England, and how this impacts on constructions of authentic Irishness. Over the course of my research on discourses of Irish authenticity in England ${ }^{\text {ix }}$, participants regularly drew on St. Patrick's Day celebrations and their own participation or non-participation in such events as a means both of articulating their understanding of 'authentic' Irishness, and of situating their own Irish identities within a collective Irishness in England. In common with my more general findings (Scully, 2010a), such articulations at times drew on narratives of the collective experience of the Irish in England, and in specific English cities, at times prioritised transnational understandings of Irishness, and at other times, re-articulated Irishness as diasporic.

The extracts presented in this paper focus on London and Birmingham as two specific sites of negotiation and contestation of how Irishness is performed in English cities. Of course, as already discussed, the demographics of the Irish vary from city to city, and it is therefore difficult to conclusively make general points about the performance of Irishness in England from this data. However, having said that, distinct patterns emerge among my participants along the lines of age and birthplace when discussing the role St. Patrick's Day has played in their lives. In particular, there appears to be a difference in the accounts of those who had experienced the community-oriented parades prior to celebrations of St. Patrick's Day being 'driven underground' during the suspect community period and those whose main experience of St. Patrick's festivals in England had been of the more recent spectacle-oriented variety. Discourses of the 'parade as inward-looking community event' and 'parade as outwardlooking spectacle' intercut throughout narratives of how participants construct the events in relation to their own Irish identities. Additionally, the notion of an authentic Irishness is invoked, both with regard to participation in St. Patrick's Day events, and how Irishness is represented to a wider audience. For older migrants then, St. Patrick's Day was constructed as a historically important means of community solidarity in an often hostile environment. For second generation Irish people, it was closely associated with family celebrations and customs, as well as memories from school. Ambivalence towards the day was more prevalent among younger migrants who tended to construct communal celebrations as not being 
particularly relevant to their own Irishness and stress the importance of their own individuality in how they marked the day.

\section{Defiance, continuity and healing on St. Patrick's Day.}

The following extract, from my interview with $\mathrm{Peg}^{\mathrm{x}}$, a woman in her $80 \mathrm{~s}$, who moved from Ireland to London during the Second World War, illustrates the historical importance of the St. Patrick's Day parade as representing a show of strength on the part of the Irish in London:

\section{Extract 1:}

Peg: We used to have huge parades you know, the parade today is nothing, we used to have huge parades ... but then the trouble started in Ireland, and when the trouble started, people were afraid to go out in the streets so the parade got smaller, but we never gave it up cause the police told us if you gave up the day you'd never get it back so we never gave it up. If there was only twenty of us marched we marched... I think the smallest parade was, there was a big bombing, I forget where it was now there was a huge bombing somewhere and it was we - that St. Patrick's Day came just after it and that was the smallest one we ever had and it was a wet day of course, of course the police offered to take us by their van to Westminster Cathedral but we said no we have to walk, we'll walk and we did walk but there was only about, I suppose a hundred maybe a hundred and twenty of us that's all, you know but we did walk cause we were determined we weren't going to, to show our pusses like but people do, you had people on the side walk who were shouting insults at you, you know but didn't pretend to see them,

Peg's account of the pre-Troubles parades stresses their size and she attributes the dwindling size of the Parades during the suspect community period to the external pressures associated with the Troubles, with people being 'afraid to go out into the streets'. There is also an emphasis on continuity here, with Peg stressing that 'if there were only twenty of us we marched'. However, this is framed more as needing to ensure the future of the parade: the authority figure of the police is invoked to lend credence to the observation that if the parade was 'given up', they'd 'never get it back'. There is an also air of defiance to her anecdote about being determined to walk the route in the face of hostility following a major bombing.

It is worth drawing out the contrasts at this point between the 'celebratory' nature of the contemporary parades and that of Peg's account of her experiences of the parades during the suspect community period. While a dominant discourse of celebrating Irishness runs through the contemporary parades (arguably in such a way as to drown out alternative voices, or to elide past hostilities) Peg's narrative represents the parade as being a small pocket of defiance, contingent on police support, in a hostile environment. Therefore, the nature of the parade as a politically-charged discursive resource to be drawn upon has been altered dramatically.

Of course, as discussed earlier, this dramatic alteration has enabled Irishness to be publicly performed on a large scale in a way that was not previously possible. As noted by Nagle (2005), the popularity of a certain version of Irishness has meant that St. Patrick's Day has taken on the form of a carnival whereby one can be 'Irish for a day' regardless of birthplace or nationality. While it is possible for this to be read as a post-colonial co-option of the Irish national feast-day by a largely English audience, it was more usual for my participants to represent English participation in St. Patrick's Day festivities as a form of rapprochement 
between the Irish and the English. Where Peg spoke of the small numbers marching in previous decades due to intimidation and the threat of violence, large numbers participating would appear to imply that such a threat no longer exists, and that it is now 'safe' to be publicly Irish. The following extract comes from a discussion in London with two women in their forties: Sheila, who had moved from Dublin to London as a child, and Máire, a migrant who had settled in London more recently after living in a number of locations in England and Ireland.

\section{Extract 2:}

Sheila: It's where everyone can come out and; yeah, unite really I suppose would be; yeah to show the Irishness; yeah. I mean I went to St Patrick's Days parades for years and; I mean, it's been going on for years, but you might only get fifty people at it and now it's like, what is it? Quarter of a million? you know, something's happened; what's happened? Máire: Maybe it's, it's kind of like a process of healing, you know, and it has got now to the point where it's, as you say, sort of like 'coming out' almost, coming out of the closet and, and it's that idea of acceptance and

Sheila: Well to me it's [

Máire: It's sort of needed, needed to happen you know [Sheila: yeah] 'cause people had been hiding for so many years.

Sheila's own memories of the small numbers at parades in previous eras of Irishness in England act as a point of personal continuity and a comparison against which the current popularity of Irishness can be compared. Máire's description of the gradual acceptance afforded to public displays of Irishness as being like a healing process, and her use of the metaphor of 'coming out of the closet' reflect a sense of the Irish, collectively, repairing a public relationship with the majority population in almost interpersonal terms. As such, the form of Irishness that is publicly performed is constructed as being less important than the fact that it can be performed at all.

Similarly, and as already mentioned, the revival of the St. Patrick's Day parade in Birmingham became emblematic of the re-emergence of the Irish community in the city, as well as Irishness staking a claim of belonging among the other cultures in present-day Birmingham. As such, there is an overt concern with advertising Irishness among the organisers as well as providing an event in which Irish people can participate. This dual function is shown in Sam's (a migrant in his sixties) account of the contemporary festival, which he has had a role in organising at various times:

\section{Extract 3:}

Sam: But Patrick's Day will show you that everyone, who're Irish they'll all appear here in hundreds and thousands of them dressed in their green and white, and it's a jolly, jolly day, y'know, a happy day. Everybody's happy and you just know everybody is happy. And we send a great message across the city and across the world, Irish exiles; first, second, third generation, are all here, enjoying themselves. It's a great, great feeling. And up to a couple of years ago we'd only one policeman on duty here in this massive thing. 'Er but that's it; obviously times have changed and drinking gets involved y'know, so; but even at that like, it is great. Selfridges ... go green; the city goes green. We've created a civic reception in a council house during the week of the festival, which we present the Lord Mayor with shamrock, and we have an exhibition of young Irish dancers, young musicians, an odd story 
teller, and we have the old set dances with the old and the new and, as I said, we present to all the council; everybody comes to that; that's a great event y'know

Sam's account of the St. Patrick's Day celebrations illustrates the multiple levels on which the festival works. It is described as contributing to cohesion within the Irish community and providing 'first, second and third generations', with a chance to enjoy themselves in an Irish context, but 'sending a message across the city and across the world' is constructed as being of equal importance. Once again, the St. Patrick's Day parade becomes a site where Irishness as diasporic and Irishness as an aspect of the multicultural city intersect.

The question then arises as to whom exactly this message is being sent? While Sam does not explicitly address this question, it does serve to illuminate the dialogical aspect to such performances of Irishness - they always occur in the context of a real or imagined audience. Again, given the specific political context of Irishness in Birmingham, where the parade was suspended for over twenty years following the IRA bombings of the city, one can imagine that there is a perceived need to promote the Irish as upstanding members of the urban community. Sam's comment about only having 'one policeman on duty' can probably be interpreted in this light. The dialogue can almost be seen as being across time between two temporally-determined dominant versions of Irishness: the suspect community of previous years and the 'happy' community of the present day. This 'happy community' are not only an integral part of Birmingham, but are permitted to transform it for the week - physically, with regard to the Selfridges Building going green. Therefore, Sam's emphasis on the extent to which the St. Patrick's Festival is integrated into the commercial and civic life of the city is less about selling Irishness as a commodity and more about creating a space for the Irish community in the city. A reciprocal relationship is thereby constructed between the articulation of a popular, positive form of Irishness and the acceptance of Irish identities and Irish people in general.

\section{'Is this what it's about?' - St. Patrick's Day as caricature.}

While it may be an exaggeration to describe the above accounts of St. Patrick's Day celebrations as fitting into a mould of 'strategic essentialism', the focus is certainly on promoting a form of Irishness that will prove popular to a wider audience in London, or Birmingham. The opposing argument, that in seeking popularity, a reified essentialised version of Irishness is promoted was also articulated in the interviews. In the following extract, Éamonn, a man in his early thirties, who moved from Ireland to London in the early 2000s, speaks of his frustration with the way the London St. Patrick's Day parade is performed:

\section{Extract 4:}

Éamonn: the raucous kind of paddywhackery element of what passes for Irish culture in this country is not something that appeals to me. I remember initially when there was going to be a St. Patrick's day parade in London officially - you know officially sponsored by the City, I thought was a good thing, this is you know sort of recognising that we're part of it, part of the great make up of this you know World City . and then you- and I've been on it, I mean I went on it with the hurling club I was playing for, I carried a banner and all this sort of stuff and then it's the- the green foam hats and the wall-to-wall Guinness coverage and and I was just thinking, is this what it's about, is this how we advertise what being Irish is to the people who might not know an awful lot about Ireland, you know, because I can see why so many people come along because it's just throw loads of drink down your neck and 
have a rip roaring time, you don't have to think about it, you don't have to work too hard at it you know, you don't have to ask too many questions about what does that mean or where does that come from, you know the language is almost absent from those sorts of celebrations the GAA is only there in terms of people, you know wearing jerseys, with a banner there's no exhibition matches or anything like that, nobody's trying to explain this is quite an integral part of what modern Ireland is, you know it's a country with an incredibly rich literary tradition that's not really there either and all this sort of stuff I just don't fi-I-it's not that I don't feel part of it, I just don't want to be part of it, it's a caricature.

This extract covers both Éamonn's own personal participation in and reaction to St. Patrick's Day events, and also the wider topic of how Irishness ought to be represented on a major public scale. He describes his own initial enthusiastic reaction to the establishment of the parade as reflecting a hope that it would entail recognition of the contribution made by the Irish towards the 'world city' that is London, before describing his disillusionment with the actual form of the parade. His rejection of the form of Irishness portrayed as in any way relevant to his own sense of an authentic Irish identity is framed in terms of personal agency - 'It's not that I don't feel part of it, I just don't want to be part of it'. However, he also expresses concern that the Irishness performed at the St. Patrick's Day parade is the wrong, inauthentic way to advertise Irishness and that, dialogically, this will have consequences for how both Irishness as a concept and the Irish collectively are viewed. There is something of an ideological dilemma in evidence here whereby the importance of the visibility of Irishness within multicultural London is contrasted with the form of Irishness that has been made visible, and from which Éamonn distances himself. As such, this echoes Nagle's concerns around 'multiculturalism's double-bind', as discussed earlier: the importance of a politics of recognition are here, in Éamonn's view, obscured by a 'caricatured' version of Irishness characterised by 'green foam hats and wall-to-wall Guinness coverage'.

After setting up this example of 'caricatured' Irishness, he then mentions some examples that he would see as more representative of Irishness that are absent from the celebrations, such as the language, the GAA, and the 'rich literary tradition'. These latter are constructed as authentic markers of Irishness, and significantly, an 'integral part of what modern Ireland is'. The assumption that the purpose of the parade is to reflect contemporary Ireland reflects Eamon Gilmore's assertion, as discussed earlier that parades outside Ireland 'need to celebrate Ireland as it is, not as people imagine it'. This prioritisation of celebrating Irishness as it is understood in contemporary Ireland can be understood within a discourse of 'authentic Irishness through transnational knowledge'. While such an orientation may be seen as worthwhile in challenging essentialised, caricatured displays of Irishness, they hold the danger of replacing them with a territorialised conception of Irishness that could be equally restrictive to those whose sense of Irishness is not necessarily located within contemporary Ireland.

\section{Belonging on St. Patrick's Day}

Such questions open up a third aspect of the importance of St. Patrick's Day celebrations that of articulating a sense of belonging. While the debate so far has been between whether the priority of the depictions of Irishness on St. Patrick's Day should be to cement the position of the Irish in England, or to offer an authentic portrayal of contemporary Ireland, a third facet of the festivities has been to offer an opportunity for those whose 'authentic' Irish identities may be questioned to claim Irishness, in particular those of Irish descent. Walter (2008a) has highlighted that there is an assumption of 'belongingness' and an ability to claim an Irish identity among those of Irish descent on St. Patrick's Day that 'are an interesting 
contrast to the uncomfortable challenges issued to the second generation in other situations that they are inauthentic Irish people, who lack an Irish birthplace and an Irish accent, and are therefore "plastic Paddies" (Walter, 2008a, p. 195). St. Patrick's Day therefore may represent an opportunity to prise open the category 'Irish' to include the imagined Irish community worldwide and thus, become a truly diasporic festival. For this reason, many of the participants, particularly those participants of Irish descent in my research, constructed St. Patrick's Day as an opportunity to promote inclusivity and belonging. In the following extract, Eileen, a second-generation woman in her 50s, discusses attending one of the early St. Patrick's Day parades in Birmingham shortly after the tradition was revived:

\section{Extract 5:}

Eileen: I would have come to maybe '97 or '98, 'cause I used to bring; I took my mother in, and leave my son at home because he was too young then. So, and I can honestly say that, you know, when they were marching past or hearing the music, it just definitely stirs something in you. It's this link, you know, it is, it is definitely a link. It's like working here because we most of us come from a second generation, it's very much you feel like a round peg in a round hole, because we don't need to go into explanations...

Eileen therefore stresses the role of the St. Patrick's Day parades in recreating belonging at an affective level, a belonging that is accentuated by her situating attending the parade in a family-based narrative. Significantly, this is also constructed as a specifically secondgeneration form of belonging, and likened to working with colleagues from similar backgrounds. Her reference to feeling like a round peg in a round hole, and not needing to 'go into explanations' or account for her specific identity or experiences, would appear to imply that this is not the norm for those of Irish descent, as outlined earlier. St. Patrick's Day, therefore, emerges as a rare occasion on which second-generation Irish people can unproblematically articulate their Irishness, as noted by Walter.

The importance of St. Patrick's Day may lie in the opportunity it affords for those who often have their Irishness challenged to articulate their own understanding of their Irish identity. However, for some of those involved in Irish community groups the once-a-year nature of St. Patrick's Day in terms of the wider community engaging with Irishness appears to be a source of frustration. This may be seen as drawing a discursive line between those who 'live' Irish and those who merely 'act' Irish when it suits them. For example, in the extract below, Becky who is herself of Irish descent, following a conversation around the difficulties of second generation Birmingham-Irish people in claiming Irishness, links these difficulties to the perception of St. Patrick's Day as 'a bandwagon':

\section{Extract 6:}

Becky: Maybe is that little bit of a feeling of 'I don't want to be called a Plastic Paddy here' you know, like I'm not jumping on the bandwagon and dressing in green, white and gold every March just because it's the hip thing to do. But I am proud of my heritage and I would like it, and I, and that's it; end of script.

Marc: (Laughs). You think there is an amount of bandwagon jumping?

Becky: Oh yeah. I mean, its amazing over the last, I would say probably five years how much that has increased. 'Erm, you notice it obviously on St Patrick's Day at the parade. You do notice it very much so, where you've got sort of friends of friends and they kind of just get caught up in the moment kind of thing, and it's great to see because it's; St Patrick's Day is for everybody to celebrate, not just the Irish and, but some people take it to 
the extreme and that's where it kind of, problems start then because you do get a bit of animosity for those who are and who aren't and, you know, feel that they have a right to be there and this other person shouldn't be there and blah blah blah.

Becky here distances herself from the possibility of being called a 'Plastic Paddy' ${ }^{\text {xi }}$ by stressing that her involvement in the St. Patrick's Day celebrations is not just 'jumping on the bandwagon ... because it's the hip thing to do' but rather due to a pride in her heritage. On my asking for elaboration on 'bandwagon jumping', she singles out St. Patrick's Day as the most obvious site where it occurs. While she emphasises that this is desirable to an extent as 'St. Patrick's Day is for everyone to celebrate', she highlights the potential inherent on the day for contestation of Irishness, particularly if people who are constructed as having a tenuous claim on Irishness ('friends of friends') 'take it to the extreme'. Becky, through drawing on the prototypical reported speech of those who would police the boundaries of participation, articulates the view that there are acceptable and unacceptable ways to express Irishness, and that those who are not positioned as sufficiently authentically Irish ought not express Irishness in an unacceptable way. Thus, while the St. Patrick's Day celebrations may provide an opportunity to articulate a diasporic claim on Irish authenticity, by expanding Irishness beyond the bounds of territorialised conceptions of 'authenticity', if the notion that 'on St. Patrick's Day everyone can be Irish' is taken too far, then it seems that this may undermine more 'genuine' claims on Irishness. Diasporic celebrations of St. Patrick's Day may therefore prise open the category 'Irish', but to what extent is still negotiated on a local basis.

\section{Conclusion}

St. Patrick's Day in England can perhaps be best characterised as a time and space where Irishness as a diasporic identity and Irishness as an ethnic identity in multicultural England are simultaneously celebrated, in both complementary and contradictory ways. As I have outlined above, this can lead to multiple inclusions and exclusions, both on the grounds of the parade itself, and potential participants being cast as inauthentic. In my research on the topic, I have argued that there are three major discourses of Irish authenticity in England: authenticity through collective experience and memory; authenticity through transnational knowledge, and authenticity through diasporic claim (Scully, 2010a). These form an explanatory framework for the various ways in which St. Patrick's Day is incorporated into individual identity work. For example, it would appear that remaining true to the collective experience of the Irish during the 'suspect community' period of the 1970s and 1980s leads to a prioritisation of the maintenance of a public space where Irishness can safely be performed, without as much emphasis on portraying an 'authentic' version of contemporary Ireland, as prioritised by the discourse of transnational knowledge. Situating St. Patrick's Day within a discourse of authenticity through diasporic claim focuses on the potential of the day to prise open the category 'Irish' in such a way as can promote belonging and inclusivity, although as discussed, the extent of this inclusivity may be contested.

Far from being an extension of a 'national' holiday abroad, St. Patrick's Day in England represents a broad set of diasporic meanings, and is a site of contestation for different discourses of Irishness, authenticity and belonging. Given the multiplicity of meanings brought to the day, Nagle is probably right to suggest that the very fluidity of the day guards against complete co-option by any one group, whether that be political or commercial forces on either side of the Irish Sea. However, merely avoiding co-option does not mean the way St. Patrick's Day is currently 'officially' celebrated in England is unproblematic. While a 
blend of strategic essentialism and community continuity may aim to be as inclusive as possible, there is always the possibility to create new forms of alienation and exclusivities in unpredictable ways.

\footnotetext{
${ }^{\mathrm{i}}$ An earlier version of this paper was originally presented at the $21^{\text {st }}$ Annual ASEN Conference - 'Forging the Nation', held at the London School of Economics and Political Science on 5-7 April 2011.

ii Prime Minister

iii Deputy Prime Minister

${ }^{\text {iv }}$ A comprehensive account of the origins of this dispute can be found in Marston (2002).

${ }^{\mathrm{v}}$ Whose own distant Irish roots and subsequently, membership of the Irish diaspora have recently been emphasised on a state visit to Ireland.

${ }^{v i}$ While my research was specifically on the Irish in England, as the Irish experience in Scotland and Wales has its own particular national specificities, it is more accurate to speak of multicultural policy in Britain. Therefore, I use the two terms interchangeably throughout the article depending on the appropriate context.

vii As an example, Buettner's (2008) social history of 'Indian' restaurants in the UK illustrates the ways in which food came to represent the totality of South Asian culture in the popular imagination.

viii It should be noted that, as highlighted by Bradley (Bradley, 2006), St. Patrick's Day parades in Scotland are still occasionally the source of contestation.

ix The research mentioned was carried out for my $\mathrm{PhD}$ at the Open University. The data extracts are taken from interviews and discussion groups I carried out with a variety of people of both Irish birth and descent in England over the course of 2008. The main sites of the research were London, Birmingham and Milton Keynes.

${ }^{\mathrm{x}}$ All names of participants have been anonymised.

${ }^{\mathrm{xi}}$ For a more detailed exploration of the way the term 'Plastic Paddy' is rhetorically managed in the identity work of second-generation Irish people in England, see Scully (2009).
}

\section{References}

Akenson, D. H. (1993). The Irish diaspora : a primer. Toronto: P.D. Meany ; Belfast : Institute of Irish Studies, The Queen's University of Belfast.

Anthias, F. (2002). Where do I belong?: Narrating collective identity and translocational positionality. Ethnicities, 2(4), 491-514.

Bradley, J. M. (2006). Sport and the Contestation of Ethnic Identity: Football and Irishness in Scotland. Journal of Ethnic and Migration Studies, 32, 1189-1208. 
Brah, A. (1996). Cartographies of diaspora : contesting identities. London: Routledge. Brubaker, R., \& Cooper, F. (2000). Beyond "identity". Theory and Society, 29(1), 1-47. Buettner, E. (2008). "Going for an Indian": South Asian Restaurants and the Limits of Multiculturalism in Britain. Journal of Modern History, 80, 865-901.

Cronin, M., \& Adair, D. (2002). The wearing of the green : a history of St Patrick's Day. London: Routledge.

Curtis, L. (1984). Nothing but the same old story: the roots of anti-Irish racism. London: Information on Ireland.

Gilroy, P. (2005). Multiculture, double consciousness and the 'war on terror'. Patterns of Prejudice, 39, 431-443.

Gray, B. (1996). Irish Women in London: National or Hybrid Diasporic Identities? . National Women's Studies Association Journal, 8(1), 85-109.

Gray, B. (1999). Longings and Belongings - Gendered Spatialities of Irishness. Irish Studies Review, 7(2), 193-210.

Gray, B. (2000). From 'Ethnicity' to 'Diaspora': 1980s Emigration and 'Multicultural' London. In A. Bielenberg (Ed.), The Irish Diaspora (pp. 65-88). Harlow: Pearson Education Ltd.

Gray, B. (2002). The Irish Diaspora: Globalised Belonging(S). Irish Journal of Sociology, 11, 123-144.

Gray, B. (2004). Women and the Irish diaspora (1st ed.). London; New York: Routledge.

Harrison, G. (2004). The Scattering: A History of the London Irish Centre, 1954-2004. London: London Irish Centre.

Hesse, B. (2000). Introduction: Un/Settled Multiculturalisms. In B. Hesse (Ed.), Un/Settled Multiculturalisms: Diasporas, Entanglements, Transruptions. (pp. 1-30). New York: Zed Books.

Hickman, M. J. (1998). Reconstructing deconstructing 'race': British political discourses about the Irish in Britain. Ethnic and Racial Studies, 21(2), 288-307.

Hickman, M. J. (2002). 'Locating' the Irish Diaspora. Irish Journal of Sociology, 11, 8-26.

Hickman, M. J., Morgan, S., Walter, B., \& Bradley, J. (2005). The Limitations of Whiteness and the Boundaries of Englishness. Ethnicities, 5(2), 160-182.

Hillyard, P. (1993). Suspect community : people's experience of the Prevention of Terrorism Acts in Britain. London: Pluto Press in association with Liberty.

Kells, M. (1995). 'I'm myself and nobody else': gender and ethnicity among young middleclass Irish women in London. In P. O'Sullivan (Ed.), Irish Women and Irish Migration (pp. 201-234). London: Leicester University Press.

Leonard, M. (2005). Performing identities: music and dance in the Irish communities of Coventry and Liverpool. Social \& Cultural Geography, 6(4), 515-529.

Limbrick, G. (2007). A Great Day: Celebrating St. Patrick's Day in Birmingham. Birmingham: St. Patrick's Festival.

Mac an Ghaill, M. (2000). The Irish in Britain: the invisibility of ethnicity and anti-Irish racism. Journal of Ethnic and Migration Studies, 26(1), 137-147.

Mac an Ghaill, M. (2001). British Critical Theorists: The Production of the Conceptual Invisibility of the Irish Diaspora. Social Identities, 7(2), 179-202.

Mac an Ghaill, M., \& Haywood, C. (2003). Young (male) Irelanders: postcolonial ethnicities - expanding the nation and Irishness. European Journal of Cultural Studies, 6, 386403.

MacLaughlin, J. (1997). The New Vanishing Irish: Social Characteristics of 'new Wave' Irish Emigration. In J. MacLaughlin (Ed.), Location and Dislocation in contemporary Irish society (pp. 133-157). Cork: Cork University Press. 
Malik, K. (2010, 17th March). Multiculturalism undermines diversity, The Guardian [online]. Retrieved from

http://www.guardian.co.uk/commentisfree/2010/mar/17/multiculturalism-diversitypolitical-policy

Marston, S. A. (2002). Making difference: conflict over Irish identity in the New York City St. Patrick`s Day parade. Political Geography, 21(3), 373-392.

Nagle, J. (2005). "Everybody Is Irish on St. Paddy's": Ambivalence and Alterity at London's St. Patrick's Day 2002. Identities, 12(4), 563-584.

Nagle, J. (2009). Multiculturalism's double-bind : creating inclusivity, cosmopolitanism and difference. Farnham: Ashgate.

Neal, F. (1999). Irish settlement in the north-east and north-west of England in the midnineteenth century. In R. Swift \& S. Gilley (Eds.), The Irish in Victorian Britain: The Local Dimension (pp. 75-100). Dublin: Four Courts Press.

O'Doherty, C. (2011, 23/3/2011). Irish Foreign Minister criticises ban on gays in St. Patrick's Parade, The Irish Voice. Retrieved from http://www.irishcentral.com/IrishVoice/IrishForeign-Minister-criticises-ban-on-gays-in-StPatricks-Parade--118157639.html

O'Keeffe-Vigneron, G. (2008). Celebrating Irishness in London. In M.-C. Considère-Charon, P. Laplace \& M. Savaric (Eds.), The Irish Celebrating: Festive and Tragic Overtones (pp. 180-191). Newcastle: Cambridge Scholars Publishing.

Phoenix, A. (1998). Dealing with difference: the recursive and the new. Ethnic and Racial Studies, 21(5), 859-880.

Scully, M. (2009). 'Plastic and Proud'? Discourses of Authenticity among the SecondGeneration Irish in England. Psychology \& Society, 2(2), 124-135.

Scully, M. (2010a). Discourses of authenticity and national identity among the Irish diaspora in England. $(\mathrm{PhD})$, The Open University, Milton Keynes. Retrieved from http://oro.open.ac.uk/25474/

Scully, M. (2010b). Local Identification and Authenticity among the Irish Diaspora in England. In L. De Pretto, G. Macri \& C. Wong (Eds.), Diasporas: Revisiting \& Discovering (pp. 225-244). Oxford: Inter-Disciplinary Press.

St. Patrick's Festival. (2010). About Us: History Retrieved 26th February 2010, from http://www.stpatricksfestival.ie/cms/aboutus history.html

Sweeney, K. (2010, 18th February). Fun, fireworks and parties to mark St. Patrick's Day, The Irish Independent. Retrieved from http://www.independent.ie/lifestyle/st-patricksday/fun-fireworks-and-parties-to-mark-st-patricks-day-2068540.html

Taylor, C. (1994). The Politics of Recognition. In D. T. Goldberg (Ed.), Multiculturalism: A Critical Reader (pp. 75-106). Oxford: Blackwell.

Walter, B. (2001). Outsiders inside : whiteness, place and Irish women. London: Routledge.

Walter, B. (2008a). Celebrations of Irishness in Britain: Second-Generation Experiences of St. Patrick's Day. In M.-C. Considère-Charon, P. Laplace \& M. Savaric (Eds.), The Irish Celebrating: Festive and Tragic Overtones (pp. 192-207). Newcastle: Cambridge Scholars Publishing

Walter, B. (2008b). From 'flood' to 'trickle': Irish migration to Britain 1987-2006. Irish Geography, 41, 181-194. 